\title{
Two new species of the gorgonian inhabiting barnacle, Conopea (Crustacea, Cirripedia,Thoracica), from the Gulf of Guinea
}

\author{
Dana Carrison-Stone ${ }^{1, \dagger}$, Robert Van Syoc ${ }^{1, \neq}$, Gary Williams ${ }^{1, \$}$, W. Brian Simison ${ }^{2,1}$ \\ I Department of Invertebrate Zoology and Geology, California Academy of Sciences, 55 Music Concourse Dr., \\ San Francisco, CA 94118, USA 2 Center for Comparative Genomics, California Academy of Sciences, 55 \\ Music Concourse Dr., San Francisco, CA 94118, USA \\ † urn:lsid:zoobank.org:author:E8F57ACE-6C6F-4197-AACB-48A5444662B8 \\ ¥ urn:lsid:zoobank.org:author:E9C678E6-0091-43ED-8AA5-C8044FC4D3F1 \\ § urn:lsid:zoobank.org:author:4BD094B7-F9C6-4FB5-89F4-3BAAFF46DD96 \\ | urn:lsid:zoobank.org:author:6E7A2C53-F0A8-4E6B-8111-A5BF4ACFFF48 \\ Corresponding author: Dana Carrison-Stone (dcarrison@calacademy.org)
}

Academic editor: Niel Bruce | Received 27 July 2012 | Accepted 29 January 2013 | Published 18 February 2013

urn:lsid:zoobank.org:pub:0E640728-1644-4AFB-9BOF-35021638E381

Citation: Carrison-Stone D, Syoc RV, Williams G, Simison WB (2013) Two new species of the gorgonian inhabiting barnacle, Conopea (Crustacea, Cirripedia, Thoracica), from the Gulf of Guinea. ZooKeys 270: 1-20. doi: 10.3897/ zookeys. 270.3736

\begin{abstract}
Two new species of Conopea (Say 1822) are described from the Gulf of Guinea: Conopea saotomensis sp. n. and Conopea fidelis sp. n. These two new species were collected from the historically isolated volcanic islands of São Tomé and Príncipe. The relationship between Conopea saotomensis sp. n., Conopea fidelis sp. n. and two other Atlantic barnacle species, Conopea calceola (Ellis 1758) and Conopea galeata (Linnaeus 1771), is examined. The methods employed are the construction of a molecular phylogeny using mitochondrial COI and nuclear $\mathrm{H} 3$ gene sequence data along with morphological comparisons of calcareous and cuticular body parts. It is found that Conopea saotomensis sp. n., Conopea fidelis sp. n. and Conopea calceola are most closely related to each other but the relationship among them is unresolved. Gorgonian hosts are identified. Preliminary observations show species level host specificity for $C$. fidelis sp. $\mathbf{n}$.
\end{abstract}

\section{Keywords}

Barnacle, Cirripedia, Conopea calceola, Conopea fidelis sp. n., Conopea galeata, Conopea saotomensis sp. n., COI, endemic, gorgonian, Gulf of Guinea, H3, host specificity, octocoral, phylogeny

Copyright Dana Carrison-Stone et al. This is an open access article distributed under the terms of the Creative Commons Attribution License 3.0 (CC-BY), which permits unrestricted use, distribution, and reproduction in any medium, provided the original author and source are credited. 


\section{Introduction}

The Gulf of Guinea island chain consists of Bioko, São Tomé, Príncipe, and Annobón. This study focuses on São Tomé and Príncipe, which are approximately $140 \mathrm{~km}$ apart and $274 \mathrm{~km}$ west of northern Gabon. They are the products of large shield volcanoes originating 3,000 m below the ocean's surface along the Cameroon line. São Tomé and Príncipe are old islands, 13 and 30 myo, respectively, and have never been connected to the African mainland.

\section{Genus Conopea}

Say (1822) designated a new genus Conopea to accommodate a new species, C. elongata, he described from eastern Florida. He included a previously known barnacle Balanus galeatus (=Lepas galeata Linnaeus 1771) in Conopea. Conopea elongata is later listed, by Darwin (1854), as a junior synonym of C. galeata. Say describes Conopea as 'Shell sessile, fixed, composed of two cones joined by their bases, the lines of junction carinate each side: inferior cone entire, attached by its anterior side and tip to marine bodies; with an aperture at the summit, closed by a quadrivalved operculum.'

Conopea is a widespread genus that is found in temperate and tropical oceans around the world. Currently, there are 21 described species of Conopea. In general, Conopea is not a well documented group. There is very little data on host associations, species ranges are not well defined, published descriptions are often incomplete and occasionally contain questionable information. Darwin (1854) thought Conopea to be closely related to the genera Megabalanus and Acasta whereas Hoek (1913) thought Conopea to be closely related to Balanus. All species of Conopea live in an obligate commensal symbiotic relationship with either a gorgonian or an antipatharian. The barnacle lives almost completely covered by host tissue, the basis of its shell clasps the axis of the host, with only the opercular opening exposed.

\section{Atlantic species of Conopea}

There are three known species of Conopea found in the Atlantic Ocean and Caribbean Sea: C. calceola, C. galeata, and C. merrilli. Conopea calceola was originally described from the Strait of Gibraltar, by Ellis (1758). Conopea calceola has subsequently been recorded from the Mediterranean to South Africa, the Persian Gulf to western Australia, the Indian Ocean, and Japan (see Newman and Ross 1976 for literature summary). Conopea merrilli was described from South Carolina (Zullo 1966) and has since been recorded from the west coast of Florida and Puerto Rico (see Newman and Ross 1976). Conopea galeata was described by Linnaeus in 1771 but no type locality was given and the type specimen is lost (Pilsbry 1916). Darwin (1854) gave a description of C. galeata (as Balanus galeatus) and listed its known localities as South Carolina, 
Florida, West Indies, and Central America. Pilsbry (1916) also gave a description of $C$. galeata (as Balanus galeatus) and listed the distribution as South Carolina to the West Indies and Central America, and southern California. The current distribution range of Conopea galeata is North Carolina through the West Indies, the Gulf of Mexico to Venezuela, southern California to Panama, and the Galápagos Islands (see Newman and Ross 1976).

Morphologically C. merrilli and C. galeata are clearly different and easily distinguishable from C. calceola, C. saotomensis sp. n., and C. fidelis sp. n.. Conopea calceola is morphologically similar to the Gulf of Guinea species and is therefore compared in detail to aid in future identifications. Conopea galeata was chosen over C. merrilli as an outgroup for molecular analysis because of its larger distribution range and greater availability of specimens.

\section{Materials and methods}

Approximately 40 individuals of Conopea saotomensis sp. n. and 20 individuals of Conopea fidelis sp. n. were collected from São Tomé and Príncipe by Carrison-Stone, Van Syoc, and Williams in 2006 and 2009. Barnacles were collected from three different localities on São Tomé: Diogo Vaz $\left(0^{\circ} 18.89^{\prime} \mathrm{N}, 6^{\circ} 29.39^{\prime \prime E}\right)$, Ponta Baleia $\left(0^{\circ} 2.13^{\prime} \mathrm{N}\right.$, $\left.6^{\circ} 33.51^{\prime} \mathrm{E}\right)$, and Ilheu Santana $\left(0^{\circ} 16^{\prime} \mathrm{N}, 6^{\circ} 45.48^{\prime} \mathrm{E}\right)$ and two different localities on Príncipe: Ilheu BomBom ( $\left.1^{\circ} 42^{\prime} 8.8^{\prime \prime} \mathrm{N}, 7^{\circ} 24^{\prime} 14^{\prime \prime E}\right)$ and Pedra de Galé $\left(1^{\circ} 43^{\prime} 30.1^{\prime \prime N}\right.$, $7^{\circ} 22^{\prime} 51.5^{\prime \prime E}$ ). Collections were done via SCUBA at depths of 9-33m. Seven individuals of Conopea calceola were collected from 3 separate sites at Porto Covo, Portugal, by Van Syoc in 2008. Samples of the associated gorgonian were also collected. All specimens were preserved in $95 \% \mathrm{EtOH}$.

Conopea galeata from St. Catherine Is., Georgia (USA) were borrowed from the California Academy of Sciences Invertebrate Zoology Department (CASIZ). Conopea galeata from South Padre Is., Texas and Mexico Beach, Florida were collected by Mary Wicksten. Conopea galeata from Port Aransas, Texas were collected by Carol Cox.

Barnacle cirri, mouthparts and opercular plates from São Tomé, Príncipe, and Portugal specimens were dissected for morphological comparisons. These physical traits, along with shell shape, in particular basis shape and presence/absence of longitudinal tubes in shell wall plates, are traditionally used for identification. The cirri and mouthparts were mounted on microslides and photographed at 100x with a Leitz microscope imaging system. Images of the opercular plates were taken with a scanning electron microscope (SEM, LEO/Zeiss 1450VP).

Identification of host gorgonians was based on external and sclerite morphology. Branching patterns, polyp shape, color and sclerite types were examined. Sclerites were isolated by dissolving small amounts of gorgonian tissue in sodium hypochlorite solution, followed by rinsing with water and then $75 \%$ ethanol. Images of the sclerites were taken with SEM and Leitz optical microscope imaging systems. All gorgonians harboring barnacles were identified using Grasshoff $(1988,1992)$. However some bar- 
Table I. Data associated with the specimens used in this study.

\begin{tabular}{|c|c|c|c|c|}
\hline Barnacle taxon & Gorgonian host & $\begin{array}{l}\text { CASIZ } \\
\text { Catalog }\end{array}$ & GenBank accession's & Collection Locality \\
\hline Conopea calceola & Eunicella verrucosa & 175916 & $\begin{array}{l}\text { HQ290142, } \\
\text { HQ290155 }\end{array}$ & Porto Covo, Portugal \\
\hline Conopea ct & Eunicella verrucosa & 175917 & $\begin{array}{l}\text { HQ290143, } \\
\text { HQ290156 }\end{array}$ & Porto Covo, Portugal \\
\hline Conopea calceola & Eunicella verrucosa & 180065 & $\begin{array}{c}\text { HQ290135, } \\
\text { KC349910 }\end{array}$ & Porto Covo, Portugal \\
\hline Conopea galeata & unknown & 106216 & $\begin{array}{l}\text { HQ290146, } \\
\text { HQ290147 }\end{array}$ & $\begin{array}{c}\text { St.Catherine Is., } \\
\text { Georgia }\end{array}$ \\
\hline Conopea galeata & unknown & 184331 & JQ966287, JQ966283 & $\begin{array}{c}\text { South Padre Is., } \\
\text { Texas }\end{array}$ \\
\hline Conopea galeata & Leptogorgia setacea & 183496 & JQ966288, JQ966284 & Port Aransas, Texas \\
\hline Conopea galeata* & unknown & $\begin{array}{l}184416 \mathrm{~A} \\
184416 \mathrm{~B}\end{array}$ & \begin{tabular}{|l|} 
JQ966289, JQ966285 \\
JQ966290, JQ966286
\end{tabular} & $\begin{array}{l}\text { Mexico Beach, } \\
\text { Florida }\end{array}$ \\
\hline $\begin{array}{c}\text { Conopea } \\
\text { saotomensis sp. n. }\end{array}$ & Leptogorgia viminalis & 173189 & $\begin{array}{l}\text { HQ290134, } \\
\text { HQ290149 }\end{array}$ & Diogo Vaz, São Tomé \\
\hline $\begin{array}{c}\text { Conopea } \\
\text { saotomensis sp. n. }\end{array}$ & Eunicella kochi & 173190 & $\begin{array}{r}\mathrm{HQ} 2 \\
\mathrm{KC} 3 \\
\end{array}$ & Diogo Vaz, São Tomé \\
\hline $\begin{array}{c}\text { Conopea } \\
\text { saotomensis sp. n. }\end{array}$ & Leptogorgia ruberrima & 174321 & КС349913, КС349922 & $\begin{array}{c}\text { Ilheu Santana, } \\
\text { Sáo Tomé }\end{array}$ \\
\hline $\begin{array}{c}\text { Conopea } \\
\text { saotomensis sp. } \mathrm{n} \text {. }\end{array}$ & Leptogorgia dakarensis & 174804 & КС349904, КС349916 & Diogo Vaz, São Tor \\
\hline $\begin{array}{c}\text { Conopea } \\
\text { saotomensis sp. n. }\end{array}$ & Leptogorgia varians & 174805 & KC349906, КС349917 & Diogo Vaz, São Ton \\
\hline $\begin{array}{c}\text { Conopea } \\
\text { saotomensis sp. n. }\end{array}$ & Leptogorgia gaini & 174806 & $\begin{array}{c}\text { HQ290152, } \\
\text { KC349918 }\end{array}$ & Diogo Vaz, São Ton \\
\hline $\begin{array}{c}\text { Conopea } \\
\text { saotomensis sp. n. }\end{array}$ & Leptogorgia ruberrima & 175525 & КС349907, КС349919 & Diogo Vaz, São Tom \\
\hline $\begin{array}{c}\text { Conopea } \\
\text { saotomensis sp. n. }\end{array}$ & Leptogorgia dichotoma & 175526 & КС349908, КС349920 & Diogo Vaz, São Tom \\
\hline $\begin{array}{c}\text { Conopea } \\
\text { saotomensis sp. n. }\end{array}$ & unknown & 178662 & КС349909, КС349925 & Diogo Vaz, São Tomé \\
\hline $\begin{array}{c}\text { Conopea } \\
\text { saotomensis sp. n. }\end{array}$ & Leptogorgia dakarensis & 178655 & $\begin{array}{l}\text { HQ290137, } \\
\text { HQ290159 }\end{array}$ & $\begin{array}{c}\text { Bom Bom Is., } \\
\text { Príncipe }\end{array}$ \\
\hline $\begin{array}{c}\text { Conopea } \\
\text { saotomensis sp. n. }\end{array}$ & unknown & 178656 & $\begin{array}{c}\text { HQ290160, } \\
\text { KC349924 }\end{array}$ & $\begin{array}{c}\text { Bom Bom Is., } \\
\text { Príncipe }\end{array}$ \\
\hline $\begin{array}{c}\text { Conopea } \\
\text { saotomensis sp. } \mathrm{n} .\end{array}$ & Leptogorgia sp. & 180025 & JQ966291 & $\begin{array}{c}\text { Pedra de Galé, } \\
\text { Príncipe }\end{array}$ \\
\hline $\begin{array}{c}\text { Conopea } \\
\text { saotomensis sp. } \mathrm{n} .\end{array}$ & Leptogorgia dichotoma & 185253 & & Diogo Vaz, São Tom \\
\hline Conopea fidelis sp. n.* & Muriceopsis tuberculata & $\begin{array}{l}174803 \mathrm{~A} \\
174803 \mathrm{~B}\end{array}$ & $\begin{array}{c}\text { HQ290140, } \\
\text { HQ290151 } \\
\text { KC349905, KC349915 }\end{array}$ & Diogo Vaz, São Tomé \\
\hline
\end{tabular}




\begin{tabular}{|c|c|c|c|c|}
\hline Barnacle taxon & Gorgonian host & $\begin{array}{l}\text { CASIZ } \\
\text { Catalog }\end{array}$ & GenBank accession's & Collection Locality \\
\hline Conopea fidelis sp. n. & Muriceopsis tuberculata & 174320 & KC349912, KC349921 & $\begin{array}{c}\text { Ponta Baleia, São } \\
\text { Tomé }\end{array}$ \\
\hline Conopea fidelis sp. $\mathrm{n}$. & Muriceopsis tuberculata & $\begin{array}{l}174322 \mathrm{~A} \\
174322 \mathrm{~B}\end{array}$ & $\begin{array}{c}\text { HQ290140, } \\
\text { HQ290150 } \\
\text { KC349914, KC349923 }\end{array}$ & $\begin{array}{c}\text { Ponta Baleia, São } \\
\text { Tomé }\end{array}$ \\
\hline Conopea fidelis sp. n.* & Muriceopsis tuberculata & $\begin{array}{l}178651 \mathrm{~A} \\
178651 \mathrm{~B}\end{array}$ & $\begin{array}{l}\text { HQ290138, } \\
\text { HQ290139 } \\
\text { HQ290157, } \\
\text { HQ290158 }\end{array}$ & $\begin{array}{c}\text { Pedra de Galé, } \\
\text { Príncipe }\end{array}$ \\
\hline Conopea fidelis sp. n. & Muriceopsis tuberculata & 185252 & & $\begin{array}{c}\text { Ponta Baleia, São } \\
\text { Tomé }\end{array}$ \\
\hline
\end{tabular}

* Two barnacles were used from this lot.

nacle specimens lacked host tissue and were found attached to only the gorgonian axis. Therefore, identification of those hosts was impossible.

Genomic DNA was extracted from adductor muscle tissue using the Qiagen DNeasy Blood and Tissue kit (Valencia, CA). The cytochrome c oxidase subunit I (COI) primers COI-N: TGAGAAATTATTCCGAAGGCTGG (Van Syoc 1994, 1995) and LCO 1490: GGTCAACAAATCATAAAGATATTGG (Folmer et al. 1994 ) were used to amplify approximately 700 base pairs of the mitochondrial genome (mtDNA). Additionally, the Histone 3 primers H3F: ATGGCTCGTACCAAGCAGAC VGC and H3R: ATATCCTTRGGCATRATRGTGAC (Colgan et al. 1998) were used to amplify approximately 350 base pairs of the nuclear protein coding gene (nDNA). The COI thermal profile was an initial step of $94^{\circ} \mathrm{C}$ for $3 \mathrm{~min}$, then 35 cycles of: $94^{\circ} \mathrm{C}$ for $30 \mathrm{sec}, 47^{\circ} \mathrm{C}$ for $30 \mathrm{sec}$, and $72^{\circ} \mathrm{C}$ for $1 \mathrm{~min}$. $\mathrm{H} 3$ thermal profile was 3 initial steps of $94^{\circ} \mathrm{C}$ for $3 \mathrm{~min}, 50^{\circ} \mathrm{C}$ for $2 \mathrm{~min}, 72^{\circ} \mathrm{C}$ for $2 \mathrm{~min}$, then 35 cycles of: $94^{\circ} \mathrm{C}$ for $35 \mathrm{sec}, 50^{\circ} \mathrm{C}$ for $30 \mathrm{sec}$, and $72^{\circ} \mathrm{C}$ for $40 \mathrm{sec}$. The resulting sequence data were edited in Sequencher 4.7 (Gene Codes) and BioEdit 7.0.9 (Hall 1997). Alignments were initially performed with ClustalW 1.8 and then edited by hand.

Molecular phylogeny was determined by Bayesian and likelihood analyses. Semibalanus balanoides (GenBank accession AF242660.1), another archaeobalanid, was used as an outgroup. Bayesian analyses were run in Mr. Bayes (Huelsenbeck and Ronquist 2001) for 50 million generations with a sample frequency of 1000 using the CAS CCG PhyloCluster (a 280-core Apple Xserve High Performance Computing Cluster with 8-12 GB RAM/node (232 GB total)). The concatenated dataset was partitioned into $1^{\text {st }}, 2^{\text {nd }}$, and $3^{\text {rd }}$ codon positions so that models of substitution could be estimated for each site with Mr.Modeltest 2.3 (Nylander 2004). Burn-in and convergence values were determined using Tracer v1.5 (Drummond and Rambaut 2007). Likelihood analyses were run in PAUP* 4.0b10 (Swofford 2003). Heuristic searches were performed along with bootstrap analyses; 10,000 bootstrap replicates with 10 random sequence additions to each bootstrap. The best-fit DNA substitution models were determined with Mr.Modeltest. All analyses were performed on the gene datasets separately as well as concatenated. Uncorrected nucleotide pairwise-distance matrices among and within groups were determined in MEGA 5.05 (Tamura et al. 2007). 


\section{Results}

\section{Molecular analyses}

Two major clades resulted from molecular analysis. One clade contains C. calceola, $C$. saotomensis sp. n. and C. fidelis sp. n, and the other contains C. galeata. Unfortunately, the gene data used was not sufficient to completely resolve the relationship among the three eastern Atlantic species. We do know that they are each other's closest relatives but we do not know which two of the three are most closely related. Bayesian (Fig. 1) and likelihood phylogenies, based on concatenated COI and $\mathrm{H} 3$ datasets, between $C$.

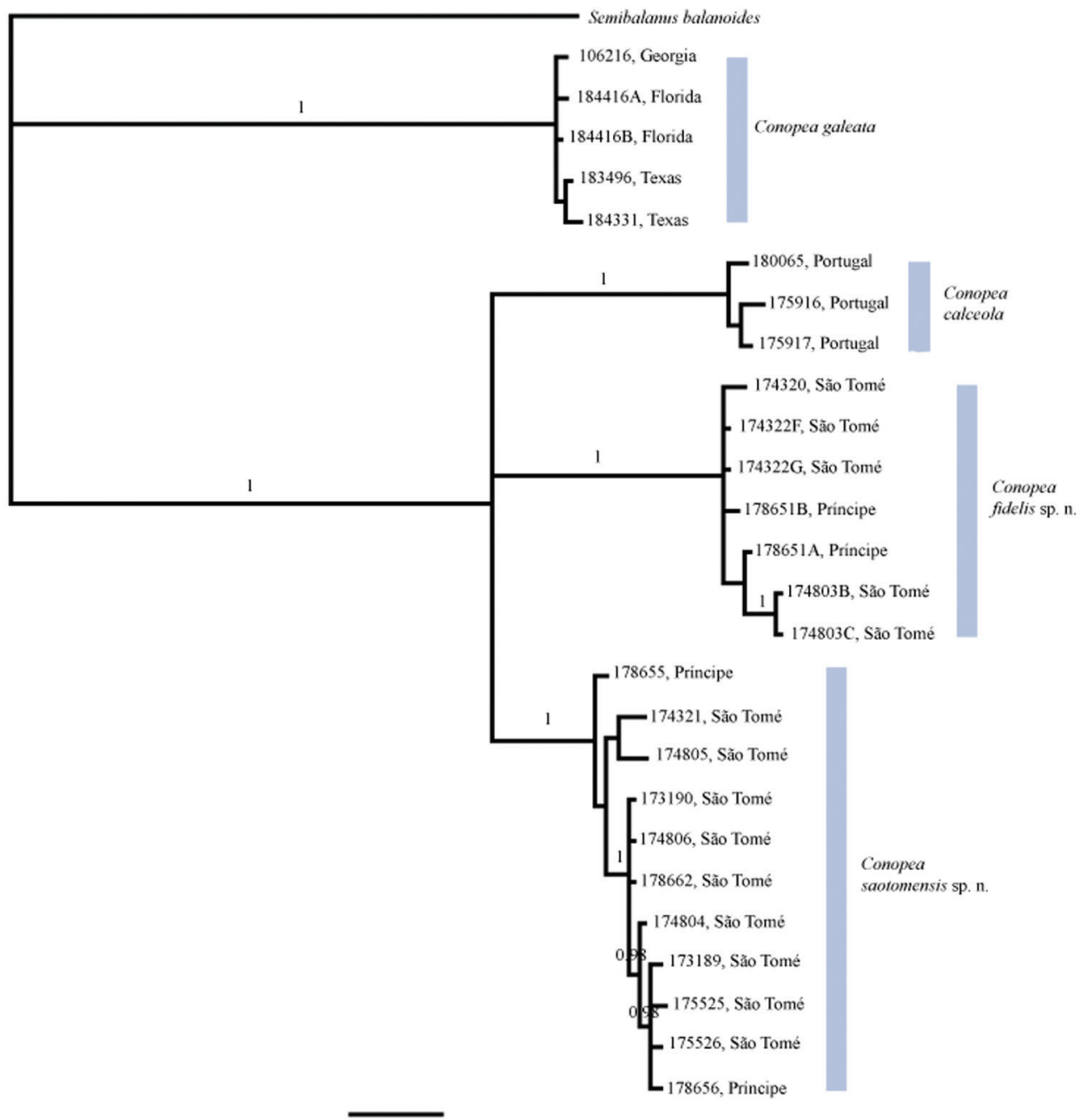

Figure I. Bayesian phylogeny based on concatenated $\mathrm{H} 3 \mathrm{nDNA}$ and $\mathrm{COI} \mathrm{mtDNA}$ sequences. Posterior probabilities of 0.95 or greater are shown. The relationship among the Gulf of Guinea species and $C$. calceola is unresolved. 
saotomensis sp. n., C. fidelis sp. n., and C. calceola are unresolved. Bayesian phylogeny generated solely on COI data shows the two Gulf of Guinea species as being more closely related to each other than to C. calceola. However the likelihood phylogeny generated with solely COI data again showed an unresolved relationship among $C$. saotomensis sp. n., C. fidelis sp. n., and C. calceola. Separate Bayesian and likelihood analyses of $\mathrm{H} 3$ sequence data showed similar unresolved topologies among the three eastern Atlantic species.

Pairwise uncorrected p-distances (Table 2) of COI and $\mathrm{H} 3$ also could not resolve the relationship. Distances for COI indicate that C. saotomensis sp. n. and Conopea fidelis sp. $\mathrm{n}$. are more closely related to each other $(8.2 \%)$ than to C. calceola $(8.8 \%$ and $10.4 \%$, respectively) whereas $\mathrm{H} 3$ distances indicate that $C$. saotomensis sp. n. and Conopea fidelis sp. n. are more closely related to C. calceola $(1.4 \%$ and $1.3 \%$, respectively) than to each other (2.2\%). Pairwise uncorrected p-distances within groups is as follows: C. saotomensis sp. n. $=0.8 \% / 0.0 \%$, C. fidelis sp. n. $=0.7 \% / 0.2 \%$, C. calceola $=$ $0.7 \% / 0.0 \%$, C. galeata $=0.3 \% / 0.1 \%(\mathrm{COI} / \mathrm{H} 3$ respectively).

Table 2. Uncorrected pairwise distances among groups, COI (lower half of matrix) and H3 (upper half of matrix).

\begin{tabular}{c|c|c|c|c}
\hline Barnacle taxon & C. saotomensis sp. $\mathbf{n}$. & C. fidelis sp. $\mathbf{n}$. & C. calceola & C. galeata \\
\hline C. saotomensis sp. n. & & 0.022 & 0.014 & 0.110 \\
\hline C. fidelis sp. n. & 0.082 & & 0.013 & 0.106 \\
\hline C. calceola & 0.088 & 0.104 & & 0.102 \\
\hline C. galeata & 0.148 & 0.165 & 0.166 & \\
\hline
\end{tabular}

\section{Systematics}

\section{Subclass Cirripedia Burmeister, 1834}

Superorder Thoracica Darwin, 1854

Order Sessilia Lamarck, 1818

Suborder Balanomorpha Pilsbry, 1916

Superfamily Balanoidea Leach, 1817

Family Archaeobalanidae Newman \& Ross, 1976

Genus Conopea Say, 1822

\section{Conopea saotomensis sp. $\mathrm{n}$.}

urn:lsid:zoobank.org:act:1164CCD8-C9F3-46E2-BBB9-1F6411123DA7

http://species-id.net/wiki/Conopea_saotomensis

Figures 2-5, Table 3

Type material. Holotype: CASIZ185253, separated from CASIZ175526, 95\% EtOH. Diogo Vaz, São Tomé, Gulf of Guinea, $0^{\circ} 18.89^{\prime} \mathrm{N}, 6^{\circ} 29.39^{\prime} \mathrm{E}$, collected by hand/SCUBA, 12-27 m, attached to Leptogorgia c.f. dichotoma, G. Williams, 29 May 2006. Original label: "S-3", California Academy of Sciences, San Francisco. 
Paratypes: CASIZ173189 (4 specimens) and CASIZ174804, Diogo Vaz, São Tomé, Gulf of Guinea $\left(0^{\circ} 18.89^{\prime} \mathrm{N}, 6^{\circ} 29.39^{\prime} \mathrm{E}\right)$, collected by hand/SCUBA, 9-26 m, R. Van Syoc, 29 May 2006; CASIZ 173190 (3 specimens), 174805 (4 specimens), 174806 (2 specimens), and 175526 (7 specimens), Diogo Vaz, São Tomé, Gulf of Guinea $\left(0^{\circ} 18.89^{\prime} \mathrm{N}, 6^{\circ} 29.39^{\prime} \mathrm{E}\right)$, collected by hand/SCUBA, 12-27 m, G. Williams, 29 May 2006; CASIZ178655 (2 specimens) and CASIZ178656 (2 specimens), Ilheu BomBom, Príncipe, Gulf of Guinea $\left(1^{\circ} 42^{\prime} 8.8^{\prime \prime N}, 7^{\circ} 24^{\prime} 14^{\prime \prime E}\right)$, collected by hand/ SCUBA, 11 m, R. Van Syoc, 24 Jan 2009.

Description. Exterior of shell with minute bumps, most prominent on parieties. Color variable, white with varying shades of purple concentrated on parietes and basis often at carina side of shell. Radii usually white but can be colored, basis lighter shade of purple to light purplish-red (Fig. 2A-B). Opercular opening round to diamond shaped, small in comparison to shell. Mantle tissue purple near opercular opening. Basis boat shaped (Fig. 2A-B) highly variable depth and length. Basis length of the paratypes $9-21 \mathrm{~mm}$. Basis elongated in rostro-carina axis, often deeply indented and/ or warped from growing around axis of gorgonian. Carina convex. Rostrum often elongate. Basis and parieties with longitudinal tubes, alae and radii solid. Tubes of basis hollow near wall plate suture where outgrowths from wall plates articulate, otherwise secondarily filled. Wall plates with small, hollow tubes close to external plate surface. Sutural margins denticulated. Shell strong, not disarticulating in sodium hypochlorite solution.

Scutum (Fig. 3A-D) with fairly straight tergal and occludent margins, occludent margin may be concave. Basal margin curved. Apex acute. Articular ridge about $2 / 3$ length of tergal margin. Articular furrow present. Adductor ridge absent. Depressor muscle pit deep, medium to large in diameter. Adductor muscle pit shallow. Interior surface of articular ridge and above adductor muscle pit rough with small flat ridges, remainder of interior surface smooth. Interior and exterior of tergum white with varying degrees of purple coloration, most often dark purple, concentrated at apex.

Tergum (Fig. 3E-H) with concave scutal and convex carinal margins, basal margin slightly convex or straight. Apex acute. Basiscutal angle shallow upper corner recessed. Spur smooth, broad, corners rounded approximately $1 / 2$ to $1 / 3$ width of tergum. Spur margin bearing 3-5 small teeth. Length of spur teeth variable. Spur furrow open. Articular ridge low $1 / 3$ to $1 / 2$ length of scutal margin. Articular furrow shallow. Depressor muscle crests faint. Interior surface rough with multiple low longitudinal ridges. Coloration matches that of scutum.

Labrum (Fig. 4A) with deep medial notch, 0-3 teeth on both or one side of notch.

Mandibular palp (Fig. 4B) elongate; superior margin convex, partially covered with long setae; apex with long setae; inferior margin with many shorter setae (Fig. 3).

Mandible (Fig. 4C) with 4-5 teeth excluding inferior angle, decreasing in size, tooth 1 largest, well separated from tooth 2, 2 separated from 3 by smaller distance, teeth 3-5 smallest and closest together, teeth 2-5 may be bidentate. Inferior margin densely setose near angle, superior margin and cutting margin below teeth sparsely setose. 

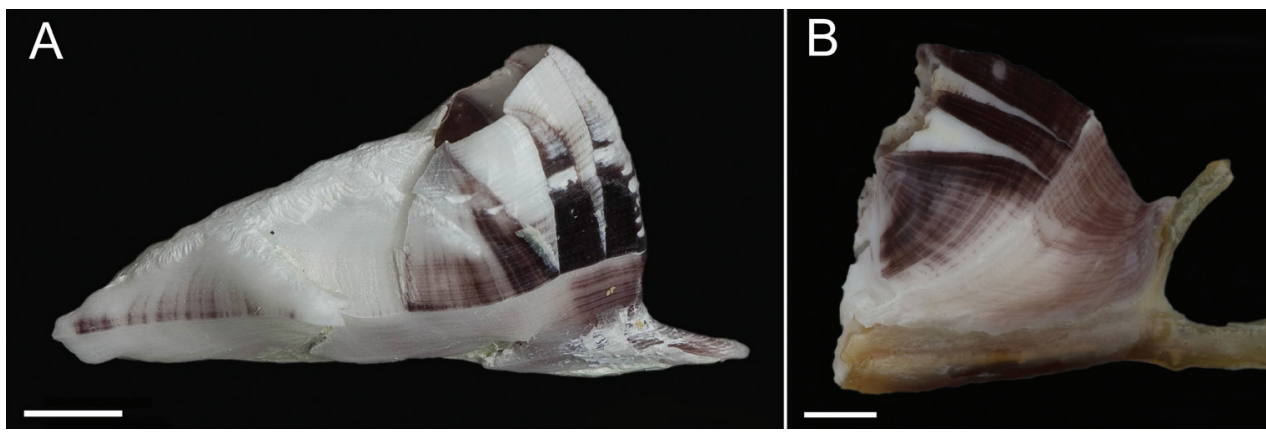

Figure 2. Conopea saotomensis sp. n., A whole shell (CASIZ174804) B whole shell attached to gorgonian axis (CASIZ174806). Scale bar $=2 \mathrm{~mm}$.

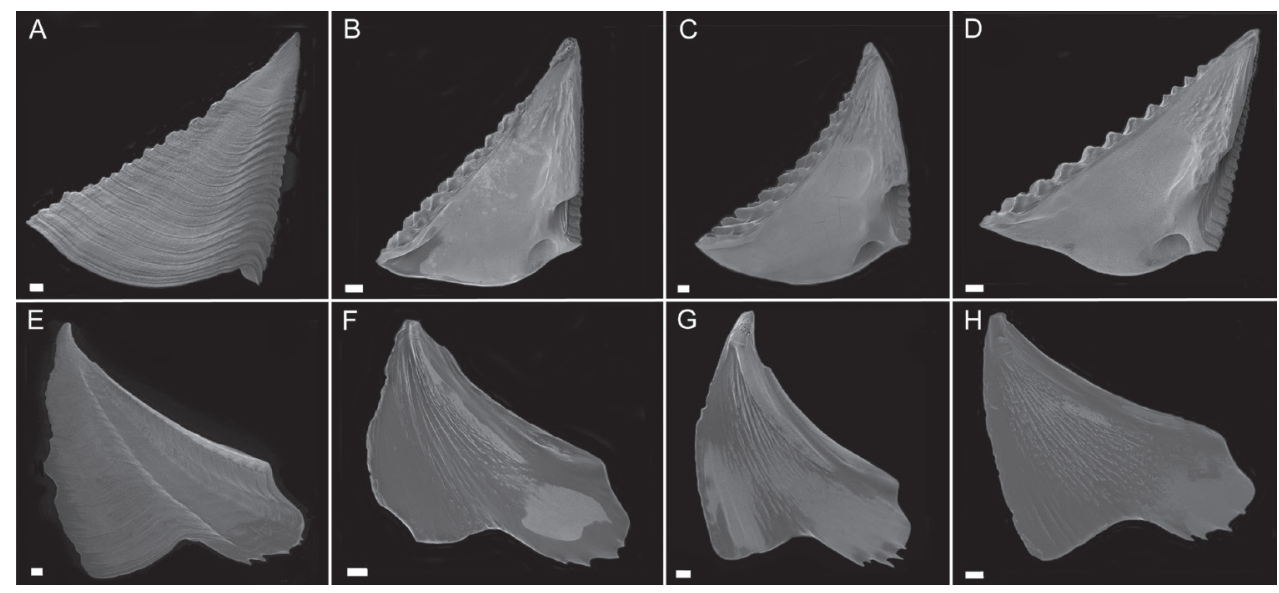

Figure 3. Conopea saotomensis sp. n. Opercular plates. A scutum exterior (CASIZ175526) B scutum interior (CASIZ178655) C scutum interior (CASIZ175526) D scutum interior (CASIZ174804) E tergum exterior (CASIZ175526) F tergum interior (CASIZ178655) G tergum interior (CASIZ175526) $\mathbf{H}$ tergum interior (CASIZ174804). Scale bar $=200 \mu \mathrm{m}$.

Table 3. Cirral formula for C. saotomensis sp. n. (CASIZ 175526; 174805; 178655)

\begin{tabular}{c|c|c|c|c|c|c}
\hline Cirrus & I & II & III & IV & V & VI \\
\hline Anterior ramus & $15-18$ & $13-16$ & $11-13$ & $17-25$ & 27 & $21-27$ \\
\hline Posterior ramus & $10-17$ & $11-13$ & $9-12$ & $21-25$ & $22-28$ & $24-29$ \\
\hline
\end{tabular}

Maxilla I (Fig. 4D-E) with 7-10 large thick spines, either evenly distributed or concentrated on $2 / 3$ of the cutting margin near superior margin, remaining cutting margin covered in short fine setae. Many fine short setae along inferior margin near cutting margin and a few fine setae along superior margin near cutting margin.

Maxilla II (Fig. 4F) small, oblong, bi-lobed, covered in long fine setae.

Cirrus I (Fig. 5A) with tapered rami, unequal in length, anterior ramus usually $1 / 3$ longer, posterior ramus more distinct segmentation, setae fine, simple, moderately dense. 

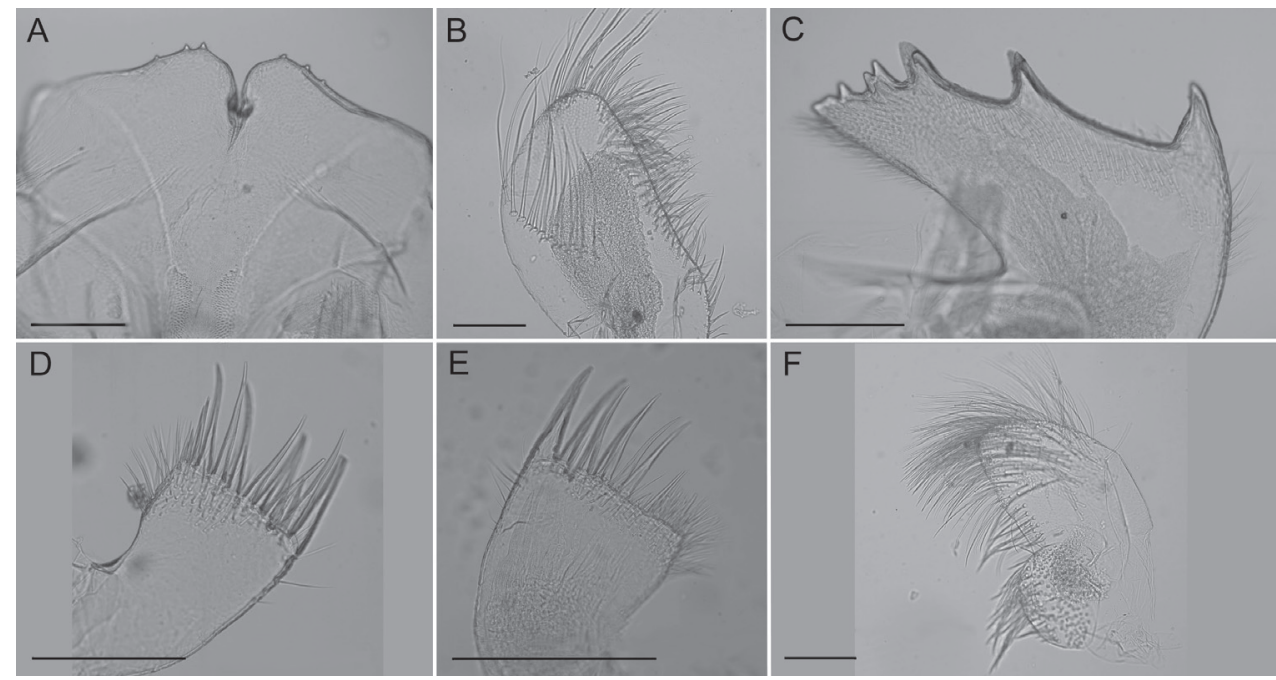

Figure 4. Conopea saotomensis sp. n. Mouth parts. A labrum (CASIZ174805) B mandibular palp (CASIZ174805) C mandible (CASIZ174805) D maxilla I (CASIZ173190) E maxilla I (CASIZ175526) F maxilla II (CASIZ178655). Scale bar $=200 \mu \mathrm{m}$.

Cirrus II (Fig. 5B) rami thick, not tapered, unequal in length but less so than CI, anterior ramus longer, setae simple and dense, segmentation distinct, annulated.

Cirrus III (Fig. 5C) rami thick, slightly tapered, disparate in length, anterior ramus longer, setae simple, dense, thicker than CI or CII, segmentation distinct, annulated.

Cirrus IV (Fig. 5D) rami long, tapered, similar length, segments 1-20, end segment varies, with small spines at base of inferior setae, setae simple, superior setae short, sparse, inferior setae long, dense (Fig. 5E).

Cirrus V (Fig. 5F) rami long, tapered, similar length, setae simple, superior setae short, sparse, inferior setae long, dense

Cirrus VI (Fig. 5G) rami long, tapered, similar length, setae simple, superior setae short, sparse, inferior setae long, dense.

All cirral setae simple.

Penis long, covered in sparse fine setae, large basidorsal point (Fig. 5H), tuft of setae distally (Fig. 5I).

Etymology. Conopea saotomensis sp. $\mathrm{n}$. is named after the island from which it was first collected, São Tomé.

Distribution. Conopea saotomensis sp. n. is known from São Tomé and Príncipe at depths ranging from 5-34 m living on species of Leptogorgia and Eunicella.

Remarks. Conopea saotomensis sp. n. differs from Conopea calceola by the following: distance between scutal depressor muscle pit and articular furrow is wider in $C$. saotomensis sp. $\mathrm{n}$. than in C. calceola; angle between tergal spur and basal margin is smaller in C. saotomensis sp. n. than in C. calceola; in C. saotomensis sp. n. large spines on cutting edge of maxilla span $2 / 3$ or entire length, span entire length in $C$. calceola. 


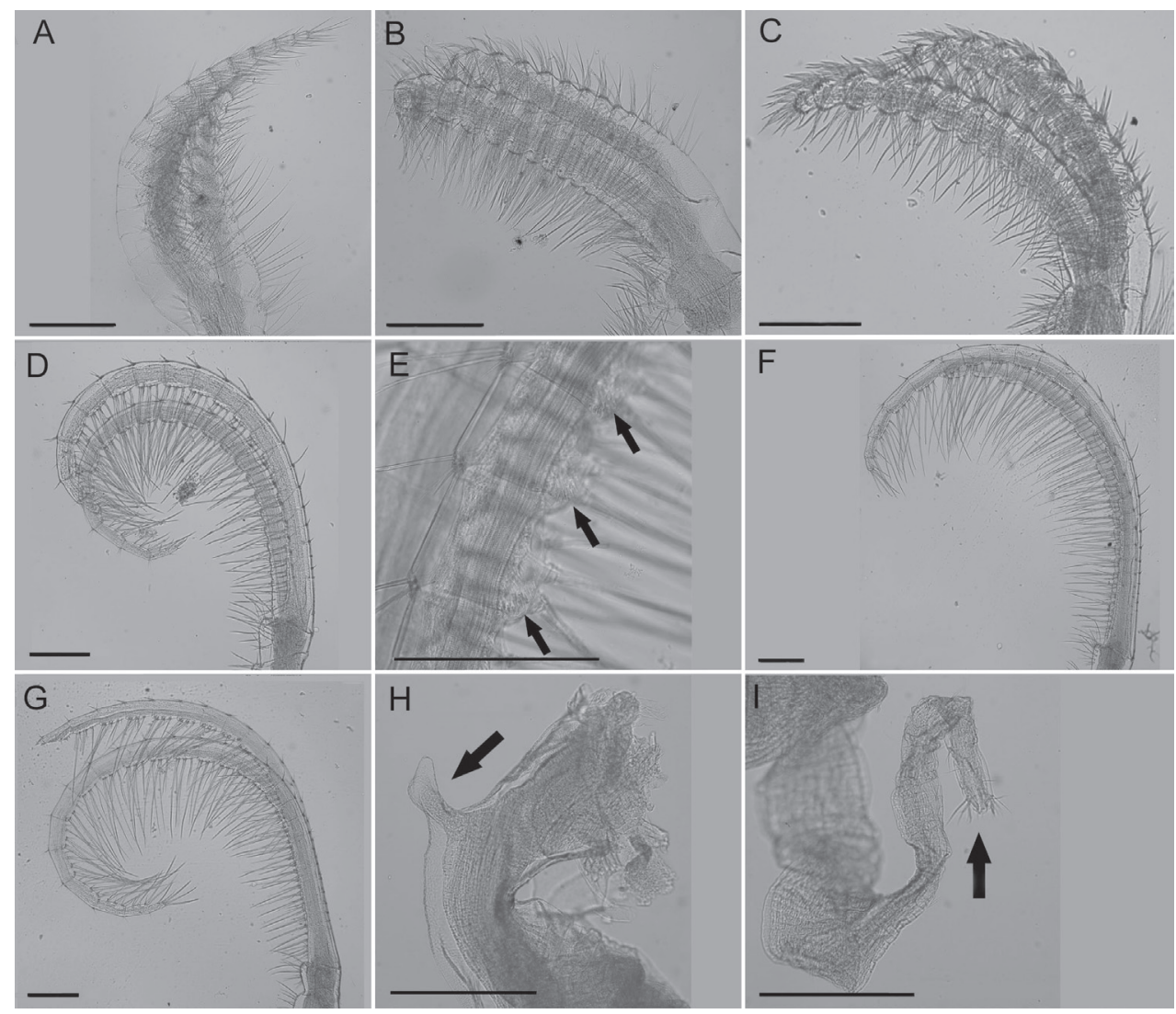

Figure 5. Conopea saotomensis sp. n. Cirri and penis. A CI (CASIZ174805) B CII (CASIZ174805) C CIII (CASIZ174805) D CIV (CASIZ174805) E CIV spines (CASIZ175526) F CV (CASIZ174805) G CVI (CASIZ174805) $\mathbf{H}$ penis basidorsal point (CASIZ175526) I penis tip (CASIZ175526). Scale bar $=200 \mu \mathrm{m}$.

\section{Conopea fidelis sp. $\mathbf{n}$.}

urn:Isid:zoobank.org:act:252522DE-A3D4-4FBA-8EF4-5D4014FED8CD http://species-id.net/wiki/Conopea_fidelis

Figures 6-9, Table 4

Type material. Holotype: CASIZ185252, separated from CASIZ174322, 95\% EtOH. Ponta Baleia, São Tomé, Gulf of Guinea, $0^{\circ} 2.13^{\prime} \mathrm{N}, 6^{\circ} 33.51^{\prime} \mathrm{E}$, collected by hand/SCUBA, 24 m, attached to Muriceopsis tuberculata, R. Van Syoc, 30 May 2006. Original label: "RVS - 539, S-6, 30 May 2006, Sao Tome" [handwritten label], California Academy of Sciences, San Francisco.

Paratypes: CASIZ174803 (2 specimens), Diogo Vaz, São Tomé, Gulf of Guinea $\left(0^{\circ} 18.89^{\prime} \mathrm{N}, 6^{\circ} 29.39^{\prime} \mathrm{E}\right)$, collected by hand/SCUBA, 9-26 m, R. Van Syoc, 29 May 2006; CASIZ174322 (14 specimens), Ponta Baleia, São Tomé, Gulf of Guinea $\left(0^{\circ} 2.13^{\prime} \mathrm{N}, 6^{\circ} 33.51^{\prime} \mathrm{E}\right)$, collected by hand/SCUBA, $24 \mathrm{~m}$, R.Van Syoc, 30 May 2006; 

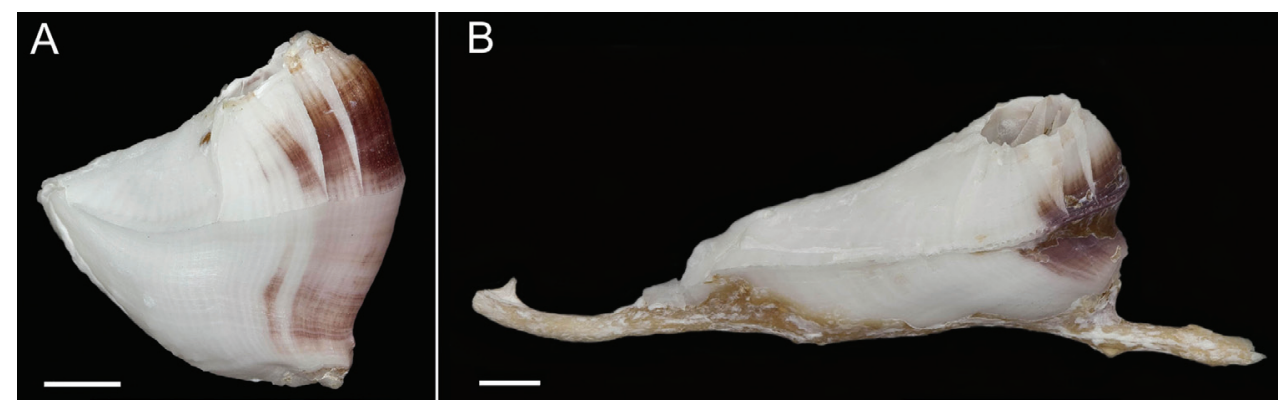

Figure 6. Conopea fidelis sp. n. A whole shell (CASIZ174322A) B whole shell attached to gorgonian axis (CASIZ174322B). Scale bar $=2 \mathrm{~mm}$.

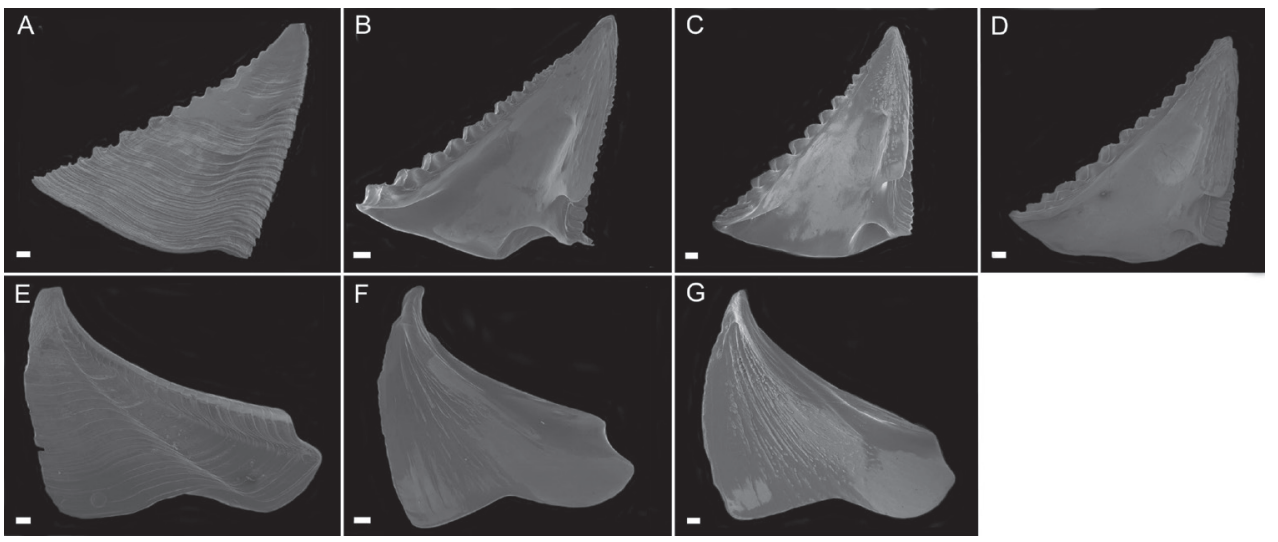

Figure 7. Conopea fidelis sp. n. Opercular plates. A scutum exterior (CASIZ174803) B scutum interior (CASIZ174322) C scutum interior (CASIZ178651) D scutum interior (CASIZ174803) E tergum exterior (CASIZ174803) F tergum interior (CASIZ174322) G tergum interior (CASIZ178651). Scale bar $=200 \mu \mathrm{m}$.

CASIZ178651 (2 specimens), Pedra da Gale, Príncipe, Gulf of Guinea (1 ${ }^{\circ} 43^{\prime} 30.1^{\prime N}$, $\left.7^{\circ} 22^{\prime} 51.5^{\prime \prime E}\right)$, collected by hand/SCUBA, 30 m, R.Van Syoc, 20 Jan 2009.

Description. Exterior of shell covered in very small bumps; color variable, white with pink or light purple on parietes and basis, radii usually white or lighter in color, rostrum often white (Fig. 6A-B). Opercular opening round to diamond shaped, small compared to shell size. Mantle tissue purple near opercular opening. Basis boat shaped (Fig. 6A-B), highly variable depth and length. Basis length of paratypes 14-32 mm. Basis elongated in rostro-carina axis, often deeply indented and/or warped from growing around axis of gorgonian. Carina convex. Rostrum often elongate. Basis with radiating longitudinal tubes, secondarily filled, hollow near wall plate suture. Wall plates with small longitudinal tubes near external surface of shell. Alae and radii lacking tubes. Sutural margins denticulated. Shell wall compartments strongly fused, not disarticulating in sodium hypochlorite solution.

Scutum (Fig. 7A-D) with straight to mildly convex tergal margin, occludent margin usually straight, occasionally with curve above basioccludent angle. Basal margin 

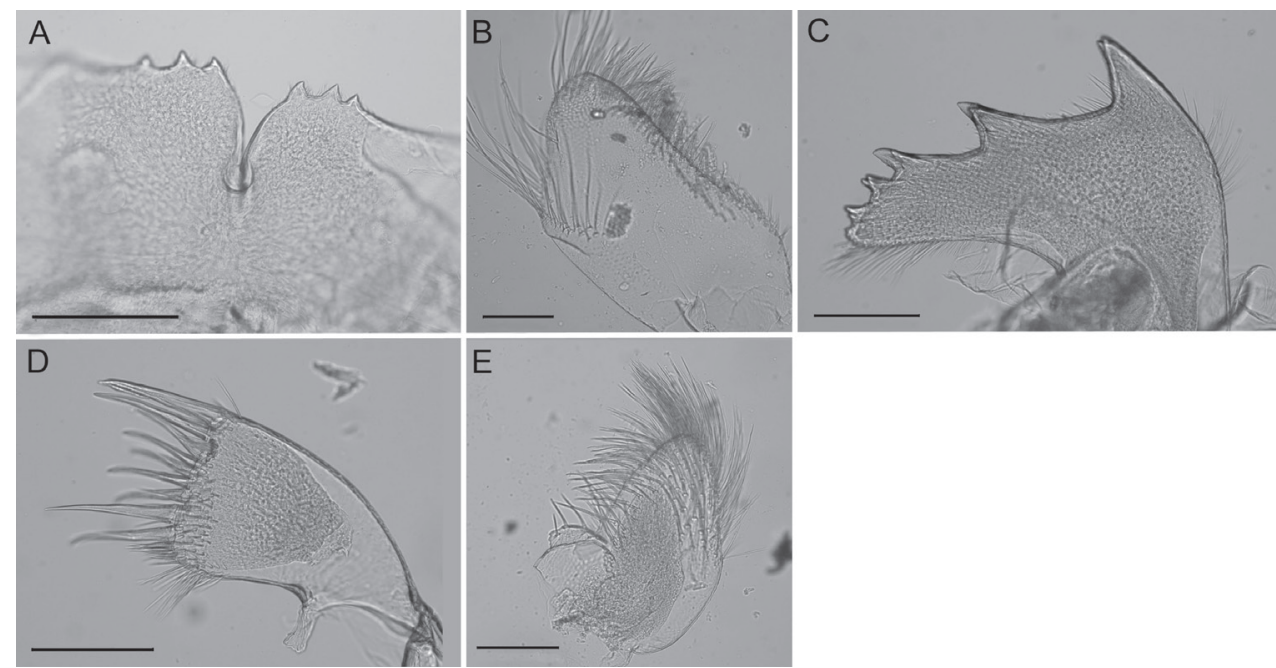

Figure 8. Conopea fidelis sp. n. Mouth parts. A: labrum (CASIZ174322) B mandibular palp (CASIZ174803) C mandible (CASIZ174322) D maxilla I (CASIZ174322) E maxilla II (CASIZ174322). Scale bar $=200 \mu \mathrm{m}$.

Table 4. Cirral formula for Conopea fidelis sp. n. (CASIZ 178651; 174803A; 174322F)

\begin{tabular}{c|c|c|c|c|c|c}
\hline Cirrus & I & II & III & IV & V & VI \\
\hline Anterior ramus & $14-17$ & $11-12$ & $11-12$ & $19-21$ & $23-24$ & $23-25$ \\
\hline Posterior ramus & $9-11$ & $9-10$ & $10-11$ & $21-22$ & $24-26$ & $23-26$ \\
\hline
\end{tabular}

variable, sinuous. Apex subacute. Articular ridge prominent, extending $2 / 3-3 / 4$ length of scutum. Articular furrow present. Adductor ridge absent. Adductor muscle pit shallow, fairly large. Depressor muscle pit large, deep, broad, may converge with basil margin. Majority of interior surface of scutum smooth, articular ridge and apex with low, flat ridges. Interior and exterior white with varying shades of purple coloration concentrated at apex.

Tergum (Fig. 7E-G) scutal and carinal margins curved. Basal margin straight or slightly curved. Apex acute. Basicutal angle shallow, upper corner recessed. Spur broad, bears no teeth, about $1 / 2$ to $1 / 3$ width of tergum, spur furrow open. Articular ridge $1 / 3$ to $1 / 2$ length of tergum. Articular furrow shallow. Depressor muscle crests faint. Interior rough with multiple small ridges. Coloration matches that of scutum.

Labrum (Fig. 8A) with deep notch, $0-3$ teeth on both or one side of notch.

Mandibular palp (Fig. 8B) slightly convex oval shape, superior margin with curved ridge and sparse fine long setae, inferior margin with dense shorter setae.

Mandible (Fig. 8C) with 4-6 teeth excluding inferior angle, decreasing in size, tooth 1 largest, well separated from tooth 2, 2 separated from 3 by smaller distance, teeth 3-6 smallest and closest together, teeth 1 and 2 may be bidentate, 4 and 5 may be bifurcated. Inferior margin densely setose near angle, superior margin and cutting margin below teeth sparsely setose. 


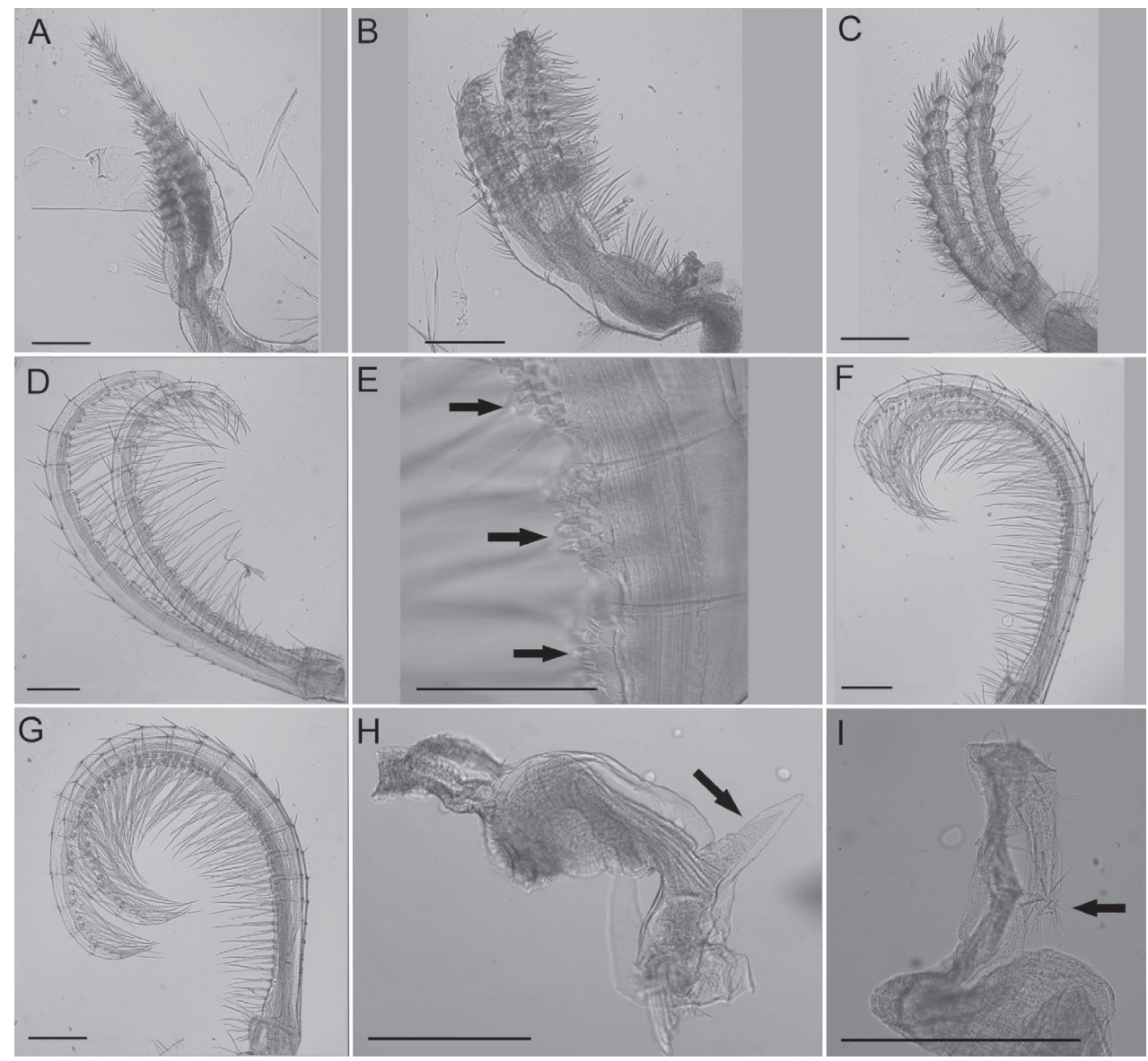

Figure 9. Conopea fidelis sp. n. Cirri and penis. A CI (CASIZ178651) B CII (CASIZ178651) C CIII (CASIZ178651) D CIV (CASIZ178651) E CIV spines (CASIZ178651) F CV (CASIZ178651) G VI (CASIZ178651) H penis basidorsal point (CASIZ174803) I penis tip (CASIZ174322). Scale bar $=200 \mu \mathrm{m}$.

Maxilla I (Fig. 8D) with 10-12 large thick spines, many smaller, thinner spines along cutting margin, short setae below margin, dense setae on anterior margin, posterior margin sparsely setose, may have shallow notch.

Maxilla II (Fig. 8E) small, oval shaped, bi-lobed, covered in long, fine setae.

Cirrus I (Fig. 9A) rami densely setose, tapered and unequal in length, anterior rami about $1 / 3$ longer, posterior rami with more annulated segmentation.

Cirrus II (Fig. 9B) rami slightly unequal in length, width thick, segmentation distinct, annulated, thick dense setae.

Cirrus III (Fig. 9C) rami unequal in length but less so than CI, anterior ramus longer, width thick, dense thick setae, segmentation distinct, annulated.

Cirrus IV (Fig. 9D) rami long, tapered, anterior side with long dense setae and small spines at base of setae (Fig. 9E) extending from first to twentieth segment (end segment variable), posterior side with short sparse setae at segment divisions. 
Cirrus V (Fig. 9F) rami long with long dense setae on anterior side and short sparse setae at segment divisions on posterior side, about equal in length.

Cirrus VI (Fig. 9G) rami long with long dense setae on anterior side, short sparse setae only at segment divisions of posterior side, similar length.

All cirral setae simple.

Penis long with large basidorsal point (Fig. 9H), covered in short very sparse setae, tuft of setae distally (Fig. 9I).

Etymology. Conopea fidelis sp. $\mathrm{n}$. is named so because it is found to be faithful to one host species of gorgonian, Muriceopsis tuberculata. From the Latin fidelis: faithful or true.

Distribution. Conopea fidelis sp. n. is known from Sáo Tomé and Príncipe at depths ranging from 5-34 $\mathrm{m}$ and is found living on the gorgonian Muriceopsis tuberculata.

Remarks. Morphological differences between Conopea fidelis sp. n. and Conopea calceola are as follows: $C$. fidelis sp. n. does not have tergal spur teeth, C. calceola does; scutal depressor muscle pit may converge with basal margin in $C$. fidelis sp. n., it does not in C. calceola; $C$. fidelis sp. n. maximum basis length is longer than that of $C$. calceola.

Morphological differences between Conopea saotomensis sp. n. and Conopea fidelis sp. n. are as follows: $C$. saotomensis sp. n. shell color ranges from dark purple to light purplish-red, $C$. fidelis sp. n. shell color ranges from light purple to pink; C. fidelis sp. $\mathrm{n}$. basis length maximum is longer than that of $C$. saotomensis sp. $\mathrm{n}$.; length of scutal articular furrow in $C$. saotomensis sp. $\mathrm{n}$. is shorter than $C$. fidelis sp. n.; scutal depressor pit may converge with basal margin in $C$. fidelis sp. n. but not in $C$. saotomensis sp. n.; angle between tergal spur and basal margin is smaller in $C$. saotomensis sp. n. than $C$. fidelis sp. n.; tergal spur teeth present in C. saotomensis sp. n., absent in C. fidelis sp. n.; C. saotomensis sp. $\mathrm{n}$. length of tergal articular ridge is equal or longer to that of $C$. fidelis sp. n.; cutting edge spines of maxilla I span entire margin or just $3 / 4$ in C. saotomensis sp. n, span entire margin in C. fidelis sp. n.; C. fidelis sp. n. maxilla I may have a notch, C. saotomensis sp. n. does not.

\section{Discussion}

COI has been shown to be useful for delimiting species within the Crustacea (Lefébure et al. 2006) and, in particular, within the Cirripedia (Van Syoc 1995, Wares 2001, Rawson et al. 2003). Costa et al. (2007) found within genus COI divergence levels of crustaceans to range from 4.92\% to 31.39\%. Van Syoc (1994) found COI divergence levels averaging $1.2 \%$ among distantly separated sub-populations of Pollicipes elegans (Lesson 1831) (Crustacea: Cirripedia: Scalpelliformes). Van Syoc (1995) and Van Syoc et al. (2010) also found a range of $15 \%-28 \%$ among species of P. elegans, P. polymerus (Sowerby 1833), and P.pollicipes (Gmelin 1790). Regarding barnacles, histone genes have been shown to be highly conserved and can be used for deep metazoan phylogenies (Pérez-Losada et al. 2004, 2008, Van Syoc et al. 2010) and for phylogenetic analysis of arthropods (Colgan et al. 1998) and thoracic barnacles (Pérez-Losada et al. 2004). Expected divergence levels of $\mathrm{H} 3$ among closely related cirriped species is not 
known but Van Syoc et al. (2010) found low levels, 0-1.3\%, of sequence divergence between species of Pollicipes. The overall difference in divergence between genes, higher for mitochondrial COI and lower for nuclear $\mathrm{H} 3$, is expected as nuclear genes typically evolve slower than mitochondrial genes for arthropods (Avise et al. 1994, Burton and Lee 1994). COI and H3 divergence levels found for C. saotomensis and C. fidelis are both satisfactory for determining a species within Cirripedia.

The barnacles collected from the Gulf of Guinea for this study were originally identified as $C$. cf. calceola. The initial identifications were tentative because $C$. calceola is not well studied, has a reportedly large distribution, the original species description (Ellis 1758) contains sparse morphological data, and Darwin's description of C. calceola (used as our reference for morphology) relied on locality for identification. Ellis (1758) designated the type locality of $C$. calceola as the Strait of Gibraltar, which connects the eastern Atlantic Ocean to the Mediterranean Sea. Darwin (1854) recorded the presence of $C$. calceola off the west coast of Africa. For his identification he noted that the original description of $C$. calceola, by Ellis, does not adequately distinguish any morphological characters for positive identification so he relied on locality, the eastern Atlantic. The C. calceola specimens from Portugal used in our phylogenetic and morphological analyses match the morphology of the specimens from the coast of Africa that Darwin described as C. calceola.

Attempts to obtain specimens of $C$. calceola from other locations/institutions were unsuccessful. Darwin's (1854) description of C. calceola was used as the guideline for the species along with the literature of Hoek (1913), (Hiro 1937), and Ren and Liu (1978). Unfortunately, none of these papers state the number of tergal spur teeth and the images are too poor to count them accurately. Therefore, a comparison of number of tergal spur teeth could not be made. But there is a difference between the 7 Portuguese $C$. calceola specimens of this paper and $C$. saotomensis sp. n. Conopea calceola was found to have 6-9 tergal spur teeth and C. saotomensis sp. n. 3-5.

\section{Gorgonian host preference}

Barnacles are found permanently attached to many different types of living and nonliving substrata. Locating a living substratum, especially one that is mobile or spatially rare, can be challenging for a small marine larva. For example; a gorgonian, a turtle, or a whale is harder to locate than a rock bed. When barnacle larvae locate and settle onto a gorgonian they may be recognizing the substratum, the presence of conspecifics, or both. It has been shown that barnacle larvae can determine where to settle by recognizing pheromone cues from their cohorts (Crisp and Meadows 1962, Knight-Jones 1995, Dreanno et al. 2006, 2007) or chemical cues from their host (Pasternak et al. 2004, Nogata and Matsumura 2005). It has also been shown that gorgonians produce barnacle settlement inducers as well as inhibitors (Standing et al. 1983) and prostaglandins that promote hatching (Clare et al. 1985). The inhibitors are water soluble 
and so found in the water near the gorgonian whereas the inducers are found absorbed in the gorgonian tissue.

Although the details of the settling barnacle larvae and gorgonian interaction are not completely known, it appears, from our observations (specifically that Conopea fidelis sp. $\mathrm{n}$. was found only on Muriceopsis tuberculata) that barnacle larvae may be capable of distinguishing between gorgonian species. Of course, more collections, identifications, and laboratory work testing settlement preference would be needed to answer this question.

\section{Endemism}

The possibility that Conopea saotomensis sp. $\mathrm{n}$. and Conopea fidelis sp. n. are endemic to the Gulf of Guinea Islands is likely for the following reasons: the islands' distance (approx. $274 \mathrm{~km}$ ), age (approx. 13 and 30 myo), and historic isolation from mainland Africa; they are not known from any previous locality; many endemic species, terrestrial and marine, are found on the Gulf of Guinea islands (Jones 1994, Measey et al. 2007). However, further sampling from the west coast of Africa is essential to determine if they are indeed endemic.

\section{Acknowledgments}

The authors would like to thank Robert Drewes (California Academy of Sciences) for initiating and organizing biodiversity research on the Gulf of Guinea Islands; Sarah Cohen (San Francisco State University/RTC) for academic support; Ned Seligman of the Step-Up Foundation for help with collecting permits and making local contacts on the islands; Africa's Eden for lodging in São Tomé and Príncipe and dive operations in Príncipe; Mary Wicksten for specimens of Conopea galeata; Christina Piotrowski and Anna Sellas for their help in the Center for Comparative Genomics lab at the California Academy of Sciences; an anonymous referee and D. Jones for their participation as Zookeys reviewers, and editor Niel Bruce (Queensland museum). Molecular lab work was funded by a CCG student start-up grant.

\section{References}

Avise JC (1994) Molecular Markers Natural History and Evolution. Chapman \& Hall, NewYork \& London, 511 pp.

Burton RS, Lee B (1994) Nuclear and mitochondrial gene genealogies and allozyme polymorphism across a major phylogeographic break in the copepod Tigriopus californicus. Evolution 91: 5197-5201. 
Burmeister H (1834) Beiträge zur Naturgeschichte der Rankenfüsser (Cirripedia). G Reimer, Berlin, 68 pp.

Clare AS, Walker G, Holland D L, Crisp D J (1985) The hatching substance of the barnacle, Balanus balanoides (L.). Proceedings of the Royal Society of London. Series B Biological Sciences 224: 131-147. doi: 10.1098/rspb.1985.0026

Colgan DJ, McLauchlan A, Wilson GDF, Livingston SP, Edgecombe GD, Macaranas J, Cassis G, Gray MR (1998) Histone H3 and U2 snRNA DNA sequences and arthropod molecular evolution. Australian Journal of Zoology 46: 419-437. doi: 10.1071/ZO98048

Costa FO, deWaard JR, Boutillier J, Ratnasingham S, Dooh RT, Hajibabaei M, Hebert PDN (2007) Biological identifications through DNA barcodes: the case of the Crustacea. Canadian Journal of Fisheries and Aquatic Sciences 64: 272-295. doi: 10.1139/f07-008

Crisp DJ, Meadows PS (1962) The chemical basis of gregariousness in Cirripedes. Proceedings of the Royal Society of London. Series B Biological Sciences 156: 500-520. doi: 10.1098/ rspb.1962.0052

Darwin CR (1854) A Monograph on the Sub-Class Cirripedia, with Figures of All the Species. The Balanidae (or Sessile Cirripedes); the Verrucidae, etc. The Ray Society, London, 1-30.

Dreanno C, Kirby RR, Clare AS (2006) Locating the barnacle settlement pheromone: spatial and ontogenetic expression of the settlement-inducing protein complex of Balanus amphitrite. Proceedings of the Royal Society of London. Series B Biological Sciences 273: 2721-2728. doi: 10.1098/rspb.2006.3649

Dreanno C, Kirby RR, Clare AS (2007) Involvement of the barnacle settlement-inducing protein complex (SIPC) in species recognition at settlement. Journal of Experimental Marine Biology and Ecology 351: 276-282. doi: 10.1016/j.jembe.2007.07.003

Drummond AJ, Rambaut A (2007) BEAST: Bayesian evolutionary analysis by sampling trees. BMC Evolutionary Biology 7: 214. doi: 10.1186/1471-2148-7-214

Ellis J (1758) An account of several rare species of barnacles. In a letter to Mr. Isaac Romilly, F.R. S. from John Ellis, Esq: F. R. S. Philosophical Transactions 50: 845-855. doi: $10.1098 / \mathrm{rstl} .1757 .0114$

Ellis J, Solander D (1786) The natural history of many curious and uncommon zoophytes, collected from various parts of the globe by the late John Ellis. Systematically arranged and described by the late Daniel Solander. Printed for Benjamin White and Son, at Horace's Head, Fleet-Street; and Peter Elmsly, in the Strand, London, 1-208pp.

Folmer O, Black M, Hoeh W, Lutz R, Vrijenhoek R (1994) DNA primers for amplification of mitochondrial cytochrome c oxidase subunit I from diverse metazoan invertebrates. Molecular Marine Biology and Biotechnology 3: 294-299.

Gmelin JF (1788-1793) Systema naturae per regna tria naturae: secundum classes, ordines, genera, species, cum characteribus, differentiis, synonymis, locis. Caroli a Linneì, 13. edition, Lipsiae.

Grasshoff M (1988) The genus Leptogorgia (Octocorallia: Gorgoniidae) in West Africa. Atlantide Report 14: 91-147.

Grasshoff M (1992) Die Flachwasser-Gorgonarien von Europa and Westafrika (Cnidaria, Anthozoa). Courier Forschungsinstitut Senckenberg 149: 1-135.

Gray JE (1825) A synopsis of the genera of Cirripedes arranged in natural families, with a description of some new species. Annals of Philosophy, new series, 10(2): 97-107. 
Hall T (1997) BioEdit biological sequence alignment editor for Windows 95/98/NT. V5.0.9 Available from http://www.mbio.ncsu.edu/BioEdit/bioedit.html

Hoek PPC (1913) The Cirripedia of the Siboga Expedition. B. Cirripedia Sessilia. Siboga Expeditie Monograph 31b: 129-275.

Huelsenbeck JP, Ronquist F (2001) MRBAYES: Bayesian inference of phylogenetic trees. Bioinformatics 17: 754-5. doi: 10.1093/bioinformatics/17.8.754

Jones PJ (1994) Biodiversity in the Gulf of Guinea: an overview. Biodiversity and Conservation 3: 772-784. doi: 10.1007/BF00129657

Knight-Jones EW (1955) The gregarious settling reaction of barnacles as a measure of systematic affinity. Nature 174: 266. doi: 10.1038/175266a0

Lamarck JBP A de (1818) Histoire Naturelle des Animaux san Vertebres. Paris, 5: 612 pp.

Leach WE (1817) Distribution systématique de la classe des Cirripèdes. Journal de Physique, de Chimie et d'Histoire Naturelle 85: 67-69.

Lefébure T, Douady CJ, Gouy M, Gibert J (2006) Relationship between morphological taxonomy and molecular divergence within Crustacea: Proposal of a molecular threshold to help species delimitation. Molecular Phylogenetics and Evolution 40: 435-447. doi: 10.1016/j. ympev.2006.03.014

Lesson RP (1831) Illustrations de zoologie, ou, Recueil de figures d'animaux peintes d'après nature / par R.-P. Lesson ; ouvrage orné de planches dessinées et gravées par les meilleurs artistes, et servant de complément aux traités généraux ou spéciaux publiés sur l'histoire naturelle et a les tenir a. Arthus Bertrand, Paris. doi: 10.5962/bhl.title.41398

Linnaeus C (1758) Tomus I. Systema naturae per regna tria naturae, secundum classes, ordines, genera, species, cum characteribus, differentiis, synonymis, locis. Editio decima, reformata. Holmiae. Laurentii Salvii 1/4: 1-824.

Linnaeus C (1771) Mantissa plantarum altera generum editionis VI \& specierum editionis II. Laurentii Salvii , Stockholm, Sweden 6: 143-587.

Measey GJ, Vences M, Drewes RC, Chiari Y, Melo M, Bourles B (2007) Freshwater paths across the ocean: molecular phylogeny of the frog Ptychadena newtoni gives insights into amphibian colonization of oceanic islands. Journal of Biogeography 34: 7-20. doi: 10.1111/j.1365-2699.2006.01589.x

Newman WA, Ross A (1976) Revision of the balanomorph barnacles; including a catalog of the species. San Diego Society of Natural History Memoir 9: 1-108.

Nogata Y, Matsumura K (2005) Larval development and settlement of a whale barnacle. Biology Letters 2(1): 92-93. doi: 10.1098/rsbl.2005.0409

Nylander JAA (2004) MrModeltest v2. Program distributed by the author. Evolutionary Biology Centre, Uppsala University 2.

Pasternak Z, Blasius B, Achituv Y, Abelson A (2004) Host location in flow by larvae of the symbiotic barnacle Trevathana dentata using odour-gated rheotaxis. Proceedings of the Royal Society of London. Series B, Biological Sciences 271 (1549): 1745-1750. doi: 10.1098/rspb.2004.2765

Pérez-Losada M, Høeg JT, Crandall KA (2004) Unraveling the evolutionary radiation of the Thoracican barnacles using molecular and morphological evidence: a comparison of several divergence time estimation approaches. Systematic Biology 53(2): 244-264. doi: 10.1080/10635150490423458 
Pérez-Losada M, Harp M, Høeg JT, Achituv Y, Jones D, Watanabe H, Crandall KA (2008)

The tempo and mode of barnacle evolution. Molecular Phylogenetics and Evolution 46: 328-346. doi: 10.1016/j.ympev.2007.10.004

Pilsbry HA (1916) The sessile barnacles (Cirripedia) contained in the collections of the U.S.National Museum: including a monograph of the American species. Bulletin of the United States National Museum 93: 1-366. doi: 10.5479/si.03629236.93.1

Rawson PD, Macnamee R, Frick MG, Williams KL (2003) Phylogeography of the coronulid barnacle, Chelonibia testudinaria, from loggerhead sea turtles, Caretta caretta. Molecular Ecology 12: 2697-2706. doi: 10.1046/j.1365-294X.2003.01940.x

Say T (1822) An account of some marine shells of the United States. Journal of the Academy of Natural Sciences, Philadelphia 2(2): 221-248, 302-325.

Sowerby GB (1833) Pollicipes ruber and polymerus n. sp. Proceedings of the Zoological Society of London 1: 1-74.

Standing JD, Hooper IR, Costlow JD (1983) Inhibition and induction of barnacle settlement by natural products present in octocorals. Journal of Chemical Ecology 10(6): 823-834. doi: $10.1007 /$ BF00987966

Swofford DL (2003) PAUP* 4.0: Phylogenetic analysis using parsimony and other methods (software), Sinauer Associates, Sunderland, Massachusetts.

Tamura K, Dudley J, Nei M, Kumar S (2007) MEGA4; Molecular Evolutionary Genetics Analysis (MEGA) software version 4.0. Molecular Biology and Evolution 24: 1596-1599. doi: $10.1093 / \mathrm{molbev} / \mathrm{msm} 092$

Van Syoc RJ (1994) Genetic divergence between subpopulations of the eastern Pacific goose barnacle Pollicipes elegans: mitochondrial cytochrome c subunit 1 nucleotide sequences. Molecular Marine Biology and Biotechnology 3(6): 338-346.

Van Syoc RJ (1995) Barnacle mitochondrial DNA: Determining genetic relationships among species of Pollicipes. In: Schram FR, Høeg JT (Eds) New frontiers in barnacle evolution. Crustacean Issues 10. A. A. Balkema, Rotterdam, 269-296.

Van Syoc RJ, Fernandes JN, Carrison DA, Grosberg RK (2010) Molecular phylogenetics and biogeography of Pollicipes (Crustacea: Cirripedia), a Tethyan relict. Journal of Experimental Marine Biology and Ecology 392: 193-199. doi: 10.1016/j.jembe.2010.04.024

Wares J (2001) Patterns of speciation inferred from Mitochondrial DNA in North American Chthamalus (Cirripedia: Balanomorpha: Chthamaloidea). Molecular Phlylogenetics and Evolution 18(1): 104-116. doi: 10.1006/mpev.2000.0857

Zullo V (1966) Thoracic Cirripedia from the continental shelf off South Caorlina, USA. Crustaceana 11(3): 229-244. doi: 10.1163/156854066X00568 